Louisiana State University

LSU Digital Commons

Faculty Publications

Department of Biological Sciences

10-1-2006

\title{
Liana habitat associations and community structure in a Bornean lowland tropical forest
}

\author{
Saara J. DeWalt \\ Clemson University \\ Kalan Ickes \\ Clemson University \\ Reuben Nilus \\ Forest Research Centre - Sandakan \\ Kyle E. Harms \\ Louisiana State University \\ David F.R.P. Burslem \\ University of Aberdeen
}

Follow this and additional works at: https://digitalcommons.Isu.edu/biosci_pubs

\section{Recommended Citation}

DeWalt, S., Ickes, K., Nilus, R., Harms, K., \& Burslem, D. (2006). Liana habitat associations and community structure in a Bornean lowland tropical forest. Plant Ecology, 186 (2), 203-216. https://doi.org/10.1007/ s11258-006-9123-6

This Article is brought to you for free and open access by the Department of Biological Sciences at LSU Digital Commons. It has been accepted for inclusion in Faculty Publications by an authorized administrator of LSU Digital Commons. For more information, please contact ir@lsu.edu. 


\title{
Liana habitat associations and community structure in a Bornean lowland tropical forest
}

\author{
Saara J. DeWalt ${ }^{1, *}$, Kalan Ickes $^{1,2}$, Reuben Nilus ${ }^{3}$, Kyle E. Harms ${ }^{4,5}$ and \\ David F.R.P. Burslem ${ }^{2}$ \\ ${ }^{1}$ Department of Biological Sciences, Clemson University, Clemson, SC, 29634, USA; ${ }^{2}$ Plant and Soil Science, \\ School of Biological Sciences, University of Aberdeen, Cruickshank Building, St Machar Drive, Aberdeen, \\ AB24 3UU, UK, ${ }^{3}$ Forest Research Centre, P.O. Box 1407, Sandakan, 90715, Sabah, Malaysia; ${ }^{4}$ Department \\ of Biological Sciences, Louisiana State University, Baton Rouge, LA, 70803, USA; ${ }^{5}$ Smithsonian Tropical \\ Research Institute, Apdo, 2072, Balboa, Republic of Panama; *Author for correspondence (e-mail: \\ saarad@clemson.edu; phone: +1-864-656-1429; fax: +1-864-656-0435)
}

Received 17 January 2005; accepted in revised form 8 February 2006

Key words: Dipterocarp forest, Diversity, Habitat specialization, Randomization tests, Sabah, Vines

\begin{abstract}
Lianas (woody vines) contribute substantially to the diversity and structure of most tropical forests, yet little is known about the importance of habitat specialization in maintaining tropical liana diversity and the causes of variation among forests in liana abundance and species composition. We examined habitat associations, species diversity, species composition, and community structure of lianas at Sepilok Forest Reserve, Sabah, Malaysia in northeastern Borneo among three soil types that give rise to three distinct forest types of lowland tropical rain forest: alluvial, sandstone hill, and kerangas (heath) forest. Alluvial soils are more nutrient rich and have higher soil moisture than sandstone soils, whereas kerangas soils are the most nutrient poor and drought prone. Lianas $\geq 0.5-\mathrm{cm}$ in diameter were measured, tagged, and identified to species in three square 0.25 -ha plots in each forest type. The number of lianas $\geq 0.5 \mathrm{~cm}$ did not differ significantly among forest types and averaged 1348 lianas $\mathrm{ha}^{-1}$, but mean liana stem diameter, basal area, estimated biomass, species richness, and Fisher's $\alpha$ diversity index were all greater for plots in alluvial than sandstone or kerangas forests. Liana species composition also differed greatly among the three habitats, with $71 \%$ of species showing significant positive or negative habitat associations. Sandstone forests were intermediate to alluvial and kerangas forests in most aspects of liana community structure and composition, and fewer species showed significant habitat associations with this forest type. Ranking of forest types with respect to liana density, biomass, and diversity matches the ranking in soil fertility and water availability (alluvial $>$ sandstone hill $>$ kerangas). These results suggest that edaphic factors play an important role in maintaining liana species diversity and structuring liana communities.
\end{abstract}

\section{Introduction}

Variation in tropical tree composition and structure over small geographic scales (i.e. $<1 \mathrm{~km}$ ) often has been correlated with changes in topography and soil characteristics (e.g., Ashton 1964; Ashton and Hall 1992; Sabatier et al. 1997; Svenning 1999; Webb and Peart 2000). In particular, 
strong edaphic discontinuities in tropical forests, such as between terra firme and flooded areas or podzolized white-sand vs. clayey soils, produce distinct differences in forest structure and composition (Tuomisto and Ruokolainen 1994; Duivenvoorden 1995; Tuomisto and Poulsen 1996; Cannon and Leighton 2004). Even over weak environmental gradients on terra firme and nonpodzolized soils, significant habitat associations of trees and shrubs to soil nutrients or hydrology occur (e.g., Clark et al. 1998; Clark et al. 1999; Webb and Peart 2000; Harms et al. 2001; Phillips et al. 2003). With the exception of certain inventories focused on particular plant groups (e.g., Melastomataceae, palms, or pteridophytes; Tuomisto and Ruokolainen 1994; Ruokolainen et al. 1997; Vormisto et al. 2000; Tuomisto et al. 2002), most studies examining entire communities have excluded lianas (woody vines) from investigations of habitat specialization (but see Burnham 2002). Lianas are important contributors to tropical forest species diversity, structure, and dynamics (Gentry 1991; Schnitzer et al. 2000; Schnitzer and Bongers 2002). Therefore, it would be valuable to know how liana communities differ over geographically short, but potentially environmentally steep, gradients. As with trees, edaphic specialization may be one mechanism by which liana species diversity is maintained in tropical forests (Wright 2002; Schnitzer 2005).

Northern Bornean forests have been the focus of several studies of habitat specialization because they display strong edaphic discontinuities over short distances. Many lowland areas support a mix of dipterocarp forests on alluvial and sandstonederived soils as well as heath forest (called kerangas) on sandstone-derived podzolic soils. Distinct differences in forest structure and composition often are found among these three habitats (Ashton 1964; Proctor et al. 1983a; Newbery and Proctor 1984; Ashton and Hall 1992; Potts et al. 2002), such that tree density, species composition, and growth rates in lowland mixed dipterocarp forests of this region vary predictably with soil fertility, topography, and water availability (Ashton 1964; Brünig 1974; Ashton and Hall 1992).

We studied the liana community in three distinct forest types (alluvial, sandstone hill, and kerangas) at Sepilok Forest Reserve, Sabah, Malaysia to examine whether liana communities are responsive to edaphic discontinuities. In particular, we addressed the following questions: (1) Among forest types, how distinct are the liana communities with regard to density, diversity, and composition? (2) Do the rankings of forest types with respect to liana density, basal area, and diversity correspond to the rankings with respect to soil fertility and inferred soil water availability? (3) To what degree do liana species show significant habitat associations with the three forest types at Sepilok? We infer edaphic specialization from consistent and strong patterns of habitat association, while recognizing that historical factors, different levels of disturbance and light availability, or other mechanisms such as biotic interactions (e.g., herbivory) could contribute to producing such patterns (Harms et al. 2001).

\section{Methods}

\section{Study area}

Sepilok Forest Reserve (Sabah, Malaysia; $5^{\circ} 10^{\prime} \mathrm{N}$, $\left.117^{\circ} 56^{\prime} \mathrm{E}\right)$ is a 4924-ha protected area located $11 \mathrm{~km}$ to the west of Sandakan on the northeast coast of the island of Borneo (Figure 1). At the Sandakan Airport, annual rainfall averages $2929 \pm 134 \mathrm{~mm}$, and mean annual temperature ranges between 26.7 and $27.7^{\circ} \mathrm{C}$ (Nilus 2004). The wettest months fall between November and February, whereas the driest month is April (mean $92 \pm 20 \mathrm{~mm})$.

The reserve was founded by the Sabah Forest Department's Forest Research Centre in 1931 and is adjacent to the Orang Utan Rehabilitation Centre, which is administered by the Sabah Wildlife Department. The northeast and southern parts of the reserve were subjected to hand logging between 1919 and 1957, during which time about $24,262 \mathrm{~m}^{3}$ of trees over 670 ha were extracted (based on reports compiled by J. Agama in 1957, as cited in Fox 1973). In addition, lianas and some non-timber trees were removed in several hundred hectares of forest in the northern part of Sepilok in 1958. Some of our alluvial forest plots (see below) may have fallen within these previously disturbed areas. 


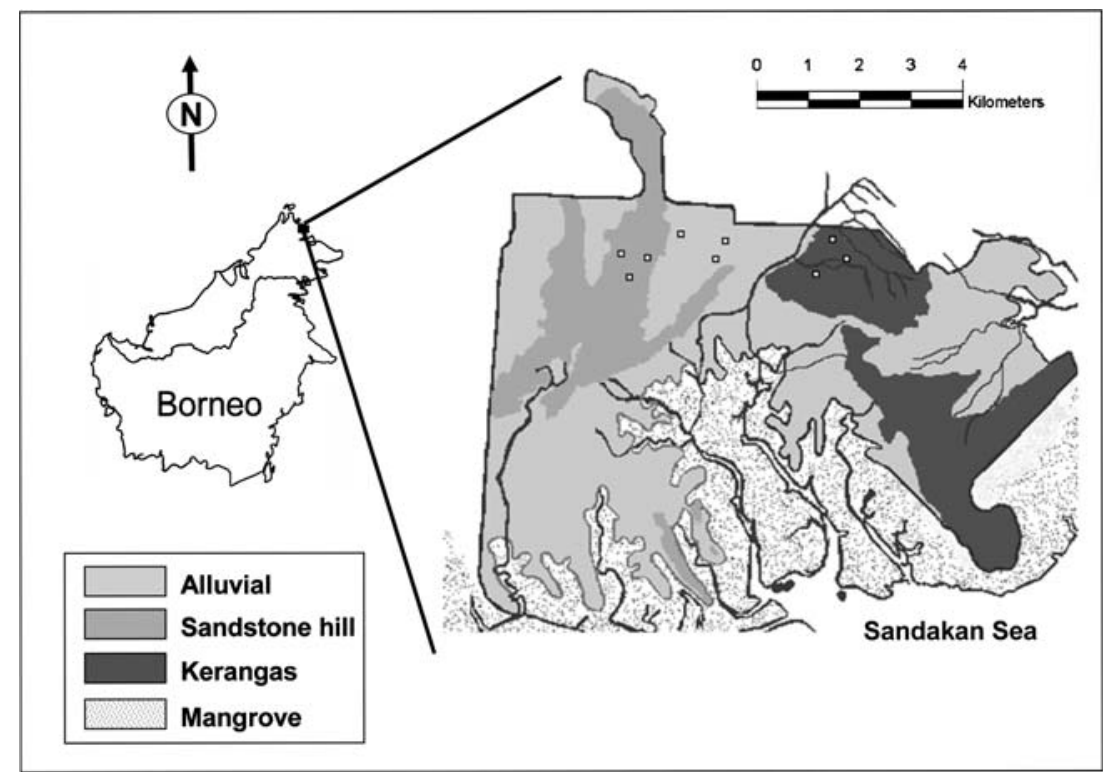

Figure 1. Map of Sepilok Forest Reserve, Malaysia showing the distribution of the three habitat types examined in this study (alluvial, sandstone hill, and kerangas forest) and the three plots per habitat type.

\section{Site descriptions}

Four forest types $0-180 \mathrm{~m}$ above sea level may be distinguished at Sepilok: alluvial lowland dipterocarp, sandstone hill dipterocarp, kerangas (heath), and mangrove (Figure 1). We did not sample the mangrove forest. The other three forest types are related to the distribution of three soil associations: Silabukan, Lokan, and Maliau, respectively (Acres and Folland 1975). Alluvial soils are derived from low mudstone and sandstone and are red-yellow podzols (Fox 1973). The topography generally is flat, and low mudstone hills rise only $15 \mathrm{~m}$. The sandstone hill soils of the Lokan association are derived from sandstone bedrock interbedded with mudstone. The topography of the sandstone hills is strongly dissected with steep slopes and narrow crests. Red-yellow podzols dominate, but lithosols are present in the upper slopes. Kerangas (heath) forest forms on the lower dip slopes of sandstone cuesta landforms on podzols and is restricted to the eastern portion of Sepilok Forest Reserve (Figure 1). This heath forest is similar in structure and physiognomy to the caatinga forest found on podzolized white sand soils in South America (Richards 1996).

The three soil types are arrayed along an axis of nutrient availability and inferred soil water availability: alluvial $>$ sandstone hill $>$ kerangas (Dent
2004; Baltzer et al. 2005). At Sepilok, alluvial soils were found to have greater concentrations of total nitrogen and phosphorus and nitrate, as well as higher gravimetric soil water content and water storage than sandstone soils (Dent 2004; Baltzer et al. 2005). Kerangas soils are coarse and sandy and generally have lower water and nutrient retention capacity than alluvial soils, which are more finely textured (Whitmore 1984). Low water retention of kerangas soils (Brünig 1974), particularly close to the soil surface, may lead to water stress for shallow-rooted plants, such as seedlings, during droughts (Tyree et al. 1998).

Structure and composition of tree communities on the three soil types also differ (Nilus 2004). Trees in kerangas forest generally are more abundant but smaller-stemmed than in alluvial forest. Sandstone forest trees are intermediate in number and size (Fox 1973). Tree diversity follows the rankings in soil nutrients: alluvial $>$ sandstone $>$ kerangas. The most common tree species $\geq 5$-cm diameter at breast height $(\mathrm{DBH})$ differ among the three forest types with the exception of Shorea multiflora (Burck) Symington (Dipterocarpaceae), which is the most common species in both sandstone and kerangas forests (Nilus 2004). Shorea xanthophylla Symington (Dipterocarpaceae), Eusideroxylon zwageri Teijsm. \& Binn. (Lauraceae), and Chisocheton beccarianus Harms 
(Meliaceae) are the most abundant species in the alluvial forest; S. multiflora, Pentace borneensis Pierre (Tiliaceae), and Dehaasia caesia Blume (Lauraceae) are the most common species in sandstone hill forest; and S. multiflora, Cleistanthus gracilis Hook.f. (Euphorbiaceae), and Tristaniopsis merguensis (Griff.) P.G.Wilson \& J.T.Waterhouse (Myrtaceae) are the most common species in the kerangas forest (Nilus 2004).

\section{Vegetation characterization}

We examined the liana community within nine $50 \times 50$-m plots $(0.25$ ha each $)$ between April and June 2000. Three plots each were located in alluvial, sandstone hill, and kerangas forest. Each liana plot was randomly located within stream-free areas of 4-ha tree plots in which trees $\geq 5$-cm DBH were measured (Nilus 2004). The forest types had been distinguished by their underlying soil textures, forest physiognomy, and topography but not species composition. The forest types presumably have arisen because of abiotic factors (such as parent material, patterns of soil weathering and accumulation, etc.), and we therefore also refer to them as 'habitats.' We did not avoid gaps in placement of liana plots. Each plot was located at least $450 \mathrm{~m}$ from other plots on the same soil type. Due to the configuration of habitats at Sepilok, the three plots in each habitat were closer to each other than to plots on another soil type. The sandstone hill plots were in the western part of the reserve, the alluvial plots in the center of the reserve, and the kerangas plots in the eastern part (Nilus 2004). Given this spatial arrangement, we would expect the liana community composition of alluvial habitats to be intermediate to those of sandstone hill and kerangas habitats if species do not specialize on particular habitats and if dispersal-assembly processes alone have governed the development of these communities (sensu Hubbell 2001).

Lianas were defined as woody climbing plants that originated from, and were permanently rooted in, the ground; thus, hemi-epiphytes were excluded. Climbing palms, Smilacaceae, Dioscoreaceae, Flagellariaceae, and Gnetum (gymnosperm) were included. Climbing bamboos, which were found only in alluvial plots, were excluded.
We measured the diameter of all lianas rooted in plots that were $\geq 0.5-\mathrm{cm}$ diameter and growing $\geq 1.3 \mathrm{~m}$ in height at some point, following the method of DeWalt et al. (2000). Both free-standing and climbing lianas that fit these criteria were included. The diameter of each liana was measured at $1.3 \mathrm{~m}$ above the ground if it was growing primarily vertically. If the liana did not ascend directly into the canopy, we measured it at its thickest point devoid of stem abnormalities. In both cases, we refer to the diameter measurement as diameter at breast height $(\mathrm{DBH})$. We used calipers to measure lianas $<4-\mathrm{cm} \mathrm{DBH}$, and cloth diameter tapes for larger stems. Flattened or irregular stems were measured twice at right angles, and the geometric average was calculated. Aboveground biomass (AGB) per stem was estimated in $\mathrm{kg}$ from diameter $(D)$ of lianas measured in $\mathrm{cm}$ using an allometric equation developed from a compilation of destructive harvest experiments in the New and Old World tropics (Schnitzer et al. In press):

$$
\mathrm{AGB}=\exp [-1.484+2.657 \ln (D)]
$$

We measured and marked apparent genets only once. When it was unclear whether stems were connected below ground, they were treated as distinct genets and each was tagged.

Lianas were identified by stem and leaf characteristics, as well as fertile material when it was available. Leaf vouchers were matched with named botanical specimens by the first two authors at the Sabah Forestry Herbarium (SAN) housed at Sepilok. Specimens were not sent to specialists for identification, thus the names assigned to species depend on the determinations of the herbarium specimens. Stems that could not be identified even to morphospecies were excluded from analyses of diversity and habitat association but were included for comparisons of density and basal area among plots.

\section{Analyses}

We tested for differences in the structure (density, basal area, and estimated biomass) and diversity of the liana community among the three habitats using one-way analysis of variance (ANOVA) in 
SAS version 8 (SAS Institute 2000). Differences among pairs of habitats were determined using post-hoc Tukey HSD tests.

We examined differences in species composition graphically using non-metric multidimensional scaling (NMS). Analyses were based on species that occurred in at least two plots (71 species). Floristic distances among pairs of plots were calculated using the metric $1-C_{\mathrm{s}}$, in which $C_{\mathrm{s}}$ is the Sørensen similarity index for presence/absence data. A distance matrix constructed using the Sørensen quantitative index provided similar results and is not presented here. We used the NMS procedure in SAS with minimum acceptable final stress set at 0.001 and maximum iterations set at 200 to obtain two- and three-dimensional graphical solutions that minimize the distortion (stress) involved in reducing multivariate data into a few dimensions (Minchin 1987).

In addition, we tested for differences in liana species composition among the three habitats with the non-parametric multiresponse permutation procedure (MRPP; Mielke 1984) using PC-ORD version 4.20. This method calculates the probability that differences detected among the habitats result from random chance. Distances among plots were calculated using $1-C_{\mathrm{N}}$, where $C_{\mathrm{N}}$ is Sørensen's quantitative similarity metric as modified by Bray and Curtis (Bray and Curtis 1957). We used the natural weighting of groups recommended by Mielke (1984). We present the chance-corrected within-group agreement statistic $(A)$ for significant MRPP analyses. The value of $A$ is analogous to 'effect size' and values close to 1 indicate high similarity of samples within groups (McCune and Grace 2002). A value of $A$ near zero in this study would indicate that heterogeneity in species composition of plots within each habitat equals that expected by chance, whereas a value near 1 would indicate that all plots are identical in species composition within their respective habitats.

To assess single-species habitat associations, we used conservative randomization tests that account for spatial structure. Other analyses, such as goodness-of-fit $\chi^{2}$ tests, do not take into account the clumped nature of plants and the non-independence of individuals. Lianas may be clumped because of single dispersal events leading to multiple individuals occurring in the same area (e.g., Webb and Peart 2000; Harms et al. 2001) or because of proliferation in localized areas such as treefall gaps (Putz 1984; Schnitzer et al. 2000; Schnitzer and Carson 2001; Ibarra-Manríquez and Martínez-Ramos 2002). We tested habitat associations only for liana species represented by at least 14 stems in the study $(n=42)$. This number of stems would have been necessary to conduct goodness-of-fit $\chi^{2}$ tests. The randomization tests consisted of 1000 iterations of shuffling habitats on which each of the nine liana plots occurred. For each iteration, we compared the observed relative density of each species to the expected relative densities generated by randomly shuffling the habitats. The observed relative density of a particular species in a particular habitat was calculated as the average across the three plots per habitat of the proportion of stems of all species belonging to that species in each plot. A species was statistically associated with a habitat if its observed relative density was more extreme than at least $97.5 \%$ of the expected relative densities (twotailed test with $\alpha=0.05$ ). A positive or negative association resulted when the observed density was greater or less, respectively, than the expected density for more than $97.5 \%$ of the randomizations.

Because of the low sample size per habitat $(n=3)$ and the conservative nature of the test, the randomization method did not detect a significant positive association of a species with a habitat unless stems of that species were found in all three plots. Similarly, significant negative associations were detected only when two criteria were met: the species was not found on any plot of that habitat and the species was found on all six plots of the other two habitats. Because of the stringency of the method, species were never detected as significantly negatively associated with more than one habitat.

\section{Results}

\section{Sepilok liana community}

Overall, 3026 lianas $\geq 0.5$-cm diameter and 412 $\geq 2.5-\mathrm{cm}$ diameter in the sampled 2.25 ha were recorded at Sepilok, producing average densities across the area of 1344 and 183 lianas $\mathrm{ha}^{-1}$, respectively. We found 107 unique species or morphospecies in 32 families and 67 genera; $14 \%$ of stems could not be reliably identified to species 
or morphospecies. The most common families were Fabaceae (475 individuals), Arecaceae (335), Annonaceae (317), Apocynaceae (216), Connaraceae (192), and Gnetaceae (187), which together composed $c a .64 \%$ of the individuals in the study. Across plots, the rattan Korthalsia rigida (Arecaceae) was the most common liana with 228 stems ( $8 \%$ of all lianas) found in seven of the nine plots.

\section{Liana community structure}

The number of lianas $\geq 0.5-\mathrm{cm}$ DBH did not differ significantly among habitats (Figure 2a; $\left.F_{2,6}=0.71, p=0.53\right)$. However, liana abundance for individuals $\geq 2.5-\mathrm{cm}$ diameter $\mathrm{ha}^{-1}$ were, on average, 377 and $225 \%$ more abundant in alluvial forests than kerangas or sandstone hill forest, respectively (Figure $2 \mathrm{~b} ; F_{2,6}=8.27, p<0.02$ ), a result attributable to greater liana stem diameters on average in alluvial than sandstone hill or kerangas forests $\left(F_{2,6}=18.3, p=0.003\right)$. The median diameter of lianas in alluvial forest $(1.3 \mathrm{~cm})$ tended to be greater than in sandstone hill $(0.88 \mathrm{~cm})$ or kerangas forest $(0.93 \mathrm{~cm})$ (Kruskal-Wallis $\chi^{2}=5.4$, d.f. $=2, p=0.07)$. Alluvial forest plots also hosted more liana basal area (Figure 2c; $F_{2,6}=34.0$, $p<0.001)$ and estimated aboveground biomass $\left(F_{2,6}=26.6, p<0.001\right)$ than kerangas and sandstone hill forest. Average liana biomass \pm SD was estimated at $7.6 \pm 1.9 \mathrm{Mg} \mathrm{ha}^{-1}$ in alluvial forest, $2.8 \pm 0.9 \mathrm{Mg} \mathrm{ha}^{-1}$ in sandstone hill forest, and $1.3 \pm 0.4 \mathrm{Mg} \mathrm{ha}^{-1}$ in kerangas forest.

The number of lianas $\geq 1-\mathrm{cm}$ DBH per hectare \pm 1 SD was $932 \pm 255$ in alluvial forest, $619 \pm 356$ in sandstone hill, and $468 \pm 276$ in kerangas. (a)

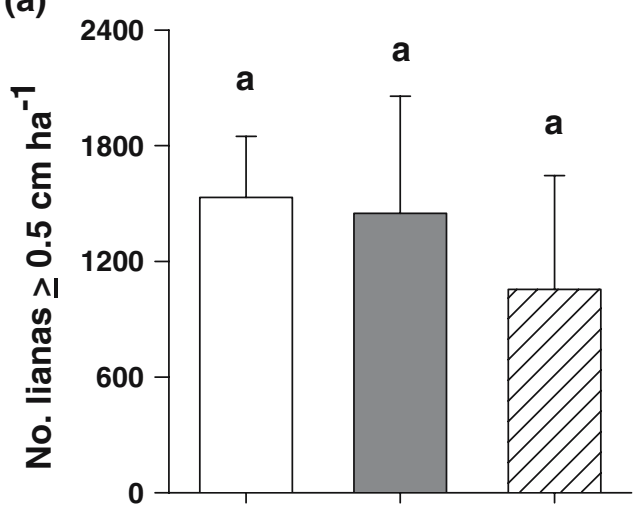

(c)

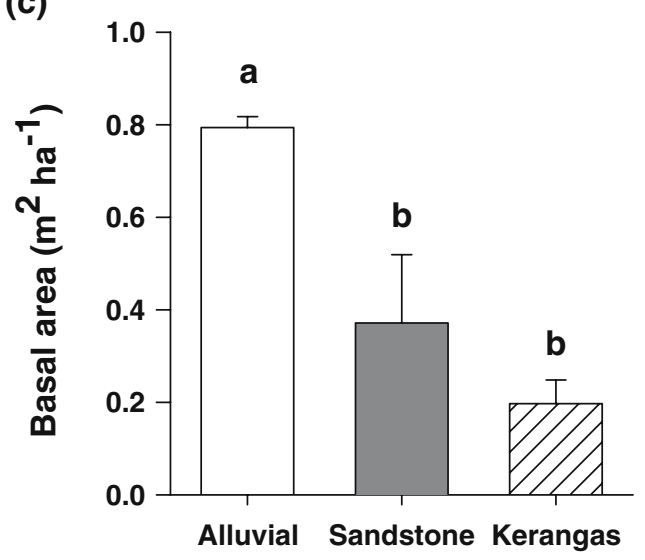

(b)

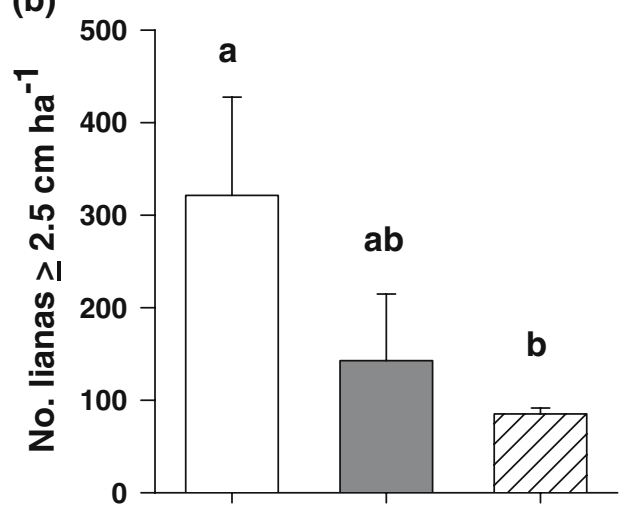

(d)

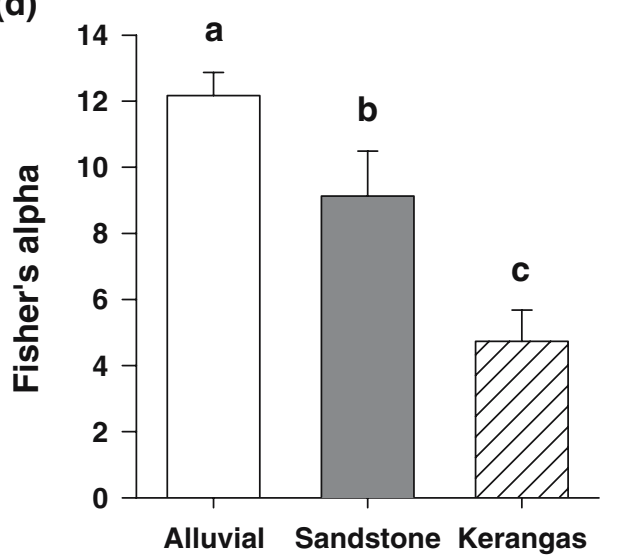

Figure 2. Mean values ( $+\mathrm{SD})$ of structural and diversity variables describing the liana community in three habitats (alluvial, sandstone hill, and kerangas forest) at Sepilok Forest Reserve, Malaysia: (a) number of lianas $\geq 0.5$-cm diameter ha ${ }^{-1}$; (b) number of lianas $\geq 2.5$-cm diameter $\mathrm{ha}^{-1}$; (c) total liana basal area ha ${ }^{-1}$; and (d) Fisher's $\alpha$ diversity index. Different letters denote significantly different means as determined by Tukey HSD tests. 
Density of lianas $\geq 2$-cm diameter was $461 \pm 158$ in alluvial forest, $197 \pm 107$ in sandstone hill, and $116 \pm 38$ in kerangas.

\section{Liana diversity and composition}

Liana diversity was highest in alluvial and lowest in kerangas plots (Figure 2d; $F_{2,6}=38.9, \quad p<$ 0.001 ); alluvial forests supported 29 and $120 \%$ more species on average than sandstone or kerangas plots. We chose Fisher's log series $\alpha$ diversity index to characterize liana diversity because it was not sensitive to sample size in our dataset (linear regression of number of individuals per plot and Fisher's $\alpha, p=0.40, n=9$ ) and generally is unaffected by sample size (Magurran 2004). The shape of the rank/abundance curves for each forest type also shows that sandstone and alluvial forest had greater evenness compared to kerangas forest (data not shown).

Kerangas forest was dominated by a single family in terms of abundance (Arecaceae) and basal area (Gnetaceae) more so than alluvial or sandstone hill forests (Table 1). Fabaceae contributed the most stems and basal area in alluvial and sandstone hill forests but was one of the least abundant families in kerangas. Arecaceae (rattans) was the most abundant family in kerangas but was not common in the other two habitats (Table 1). In kerangas, species in the Gnetaceae were less abundant than those in the Arecaceae or Apocynaceae, but Gnetum spp. were larger in diameter and contributed more basal area than species from the more common families.

In alluvial forest, the legume Spatholobus oblongifolius was most abundant ( $9 \%$ of all individuals) and contributed the most basal area $(28 \%$; Table 2). In sandstone hill forest, Tetracera korthalsii (Dilleniaceae) was the most common liana (9\%), but another legume Spatholobus maingayi contributed the most basal area $(16 \%)$. The rattan palm Korthalsia rigida was the most abundant liana in kerangas forest $(27 \%)$, whereas the gymnosperm Gnetum neglectum contributed the most basal area $(40 \%)$.

Overall, the three forest types had distinct liana communities, a point which is demonstrated graphically in the NMS ordination in which the three habitats clearly are separated by species presence/absence (Figure 3). Kerangas and sandstone hill plots were most similar in the species they shared (mean Sørensen's similarity index was 0.34). Alluvial and sandstone plots were less similar (mean $C_{\mathrm{s}}=0.23$ ), and alluvial and kerangas plots shared very few species (mean $C_{\mathrm{s}}=0.04$ ).

Table 1. Contribution of the 15 most common families to the number of individuals and basal area within 0.75 ha sampled in each habitat ( $\mathrm{A}=$ alluvial, $\mathrm{S}=$ sandstone hill, and $\mathrm{K}=$ kerangas) at Sepilok Forest Reserve, Sabah, Malaysia.

\begin{tabular}{|c|c|c|c|c|c|c|c|c|c|c|c|c|c|}
\hline \multirow[t]{2}{*}{ Family } & \multicolumn{3}{|c|}{$\begin{array}{l}\text { Number of } \\
\text { individuals }\end{array}$} & \multicolumn{3}{|c|}{$\begin{array}{l}\% \text { of individuals } \\
\text { within habitat }\end{array}$} & \multicolumn{3}{|c|}{$\begin{array}{l}\text { Basal area } \\
\left(\mathrm{cm}^{2}\right)\end{array}$} & \multicolumn{3}{|c|}{$\begin{array}{l}\% \text { of basal } \\
\text { area within habitat }\end{array}$} & \multirow[t]{2}{*}{$\begin{array}{l}\text { Number } \\
\text { of sp. }\end{array}$} \\
\hline & A & $\mathrm{S}$ & $\mathrm{K}$ & A & $\mathrm{S}$ & $\mathrm{K}$ & A & S & $\mathrm{K}$ & A & $\mathrm{S}$ & $\mathrm{K}$ & \\
\hline Annonaceae & 136 & 108 & 73 & $12 \%$ & $10 \%$ & $9 \%$ & 364.4 & 325.9 & 241.0 & $6 \%$ & $12 \%$ & $16 \%$ & 16 \\
\hline Apocynaceae & 0 & 97 & 119 & $0 \%$ & $9 \%$ & $15 \%$ & 0.0 & 282.5 & 144.7 & $0 \%$ & $10 \%$ & $10 \%$ & 4 \\
\hline Arecaceae & 9 & 14 & 312 & $1 \%$ & $1 \%$ & $39 \%$ & 5.4 & 13.4 & 249.5 & $<1 \%$ & $<1 \%$ & $17 \%$ & 4 \\
\hline Combretaceae & 55 & 33 & 0 & $5 \%$ & $3 \%$ & $0 \%$ & 182.0 & 25.4 & 0.0 & $3 \%$ & $1 \%$ & $0 \%$ & 2 \\
\hline Connaraceae & 143 & 49 & 0 & $12 \%$ & $4 \%$ & $0 \%$ & 212.8 & 47.5 & 0.0 & $4 \%$ & $2 \%$ & $0 \%$ & 2 \\
\hline Dilleniaceae & 21 & 93 & 1 & $2 \%$ & $9 \%$ & $<1 \%$ & 47.2 & 54.3 & 0.3 & $1 \%$ & $2 \%$ & $0 \%$ & 2 \\
\hline Euphorbiaceae & 45 & 32 & 0 & $4 \%$ & $3 \%$ & $0 \%$ & 123.5 & 50.9 & 0.0 & $2 \%$ & $2 \%$ & $0 \%$ & 2 \\
\hline Fabaceae & 300 & 159 & 14 & $26 \%$ & $15 \%$ & $2 \%$ & 3243.4 & 499.4 & 9.0 & $54 \%$ & $18 \%$ & $1 \%$ & 17 \\
\hline Gnetaceae & 4 & 75 & 108 & $<1 \%$ & $7 \%$ & $14 \%$ & 43.3 & 235.6 & 610.8 & $1 \%$ & $8 \%$ & $41 \%$ & 5 \\
\hline Loganiaceae & 55 & 85 & 7 & $5 \%$ & $8 \%$ & $1 \%$ & 286.1 & 325.9 & 13.0 & $5 \%$ & $12 \%$ & $1 \%$ & 5 \\
\hline Malpighiaceae & 98 & 0 & 0 & $9 \%$ & $0 \%$ & $0 \%$ & 254.3 & 0.0 & 0.0 & $4 \%$ & $0 \%$ & $0 \%$ & 1 \\
\hline Menispermaceae & 19 & 2 & 29 & $2 \%$ & $0 \%$ & $4 \%$ & 75.5 & 0.7 & 21.4 & $1 \%$ & $0 \%$ & $1 \%$ & 2 \\
\hline Rhamnaceae & 13 & 41 & 4 & $1 \%$ & $4 \%$ & $1 \%$ & 84.4 & 54.6 & 1.4 & $1 \%$ & $2 \%$ & $<1 \%$ & 3 \\
\hline Rutaceae & 16 & 80 & 0 & $1 \%$ & $7 \%$ & $0 \%$ & 39.4 & 54.9 & 0.0 & $1 \%$ & $2 \%$ & $0 \%$ & 3 \\
\hline Thymelaeaceae & 2 & 16 & 32 & $<1 \%$ & $1 \%$ & $4 \%$ & 1.8 & 30.6 & 60.3 & $<1 \%$ & $1 \%$ & $4 \%$ & 2 \\
\hline
\end{tabular}

The number of species for each family denotes those identified with a high degree of confidence. The highest values for number of individuals and basal area in each habitat are shown in bold. 
Table 2. Liana species analyzed for habitat associations at Sepilok Forest Reserve, Sabah, Malaysia.

\begin{tabular}{|c|c|c|c|c|c|}
\hline Family & Species & Species code & Alluvial & Sandstone & Kerangas \\
\hline \multirow[t]{6}{*}{ Annonaceae } & Artabotrys suaveolus (Blume) Blume & ARTASU & $0^{-}$ & $9^{3}$ & $27^{3}$ \\
\hline & Cyathostemma excelsum (Hook.f. \& Thomson) J.Sincl. & CYATEX & $98^{3+}$ & $36^{2}$ & $3^{2}$ \\
\hline & Fissistigma fulgens (Hook.f. \& Thomson) Merr. & FISSFU & 0 & $9^{2}$ & $31^{3+}$ \\
\hline & Friesodielsia glauca (Hook.f. \& Thomson) Steenis & FRIEGL & $17^{3}$ & $16^{2}$ & 0 \\
\hline & Pyramidanthe prismatica (Hook.f. \& Thomson) J.Sincl. & PYRAPR & 0 & $5^{1}$ & $11^{3+}$ \\
\hline & Unknown species 1 & ANNOM1 & 0 & $14^{3+}$ & 0 \\
\hline \multirow[t]{3}{*}{ Apocynaceae } & Alyxia reinwardtii Blume & ALYXRE & 0 & 0 & $42^{3+}$ \\
\hline & Chilocarpus vernicosus Blume & CHILVE & 0 & $36^{2}$ & $77^{3+}$ \\
\hline & Willughbeia coriacea Wall. \& G.Don & WILLCO & 0 & $49^{2}$ & 0 \\
\hline \multirow[t]{3}{*}{ Arecaceae } & Calamus javensis Blume & CALAJA & 0 & $4^{1}$ & $81^{3+}$ \\
\hline & Daemonorops longipes (Griff.) Mart. & DAEMLO & 0 & 0 & $18^{3+}$ \\
\hline & Korthalsia rigida Blume & KORTRI & $5^{1}$ & $10^{3}$ & $213^{3+}$ \\
\hline Asclepiadaceae & Dischidia major (Vahl) Merr. & DISCMA & 0 & 0 & $31^{3}$ \\
\hline \multirow[t]{2}{*}{ Combretaceae } & Combretum nigrescens King & COMBNI & $45^{3+}$ & 0 & 0 \\
\hline & Combretum sp.1 & COMBF2 & $11^{2}$ & $33^{3}$ & 0 \\
\hline \multirow[t]{2}{*}{ Connaraceae } & Agelaea borneensis (Hook.f.) Merr. & AGELBO & $33^{3}$ & $31^{3}$ & $0^{-}$ \\
\hline & Agelaea trinervis (Llanos) Merr. & AGELTR & $99^{3+}$ & $5^{1}$ & 0 \\
\hline cf. Convolvulaceae & cf. Erycibe sp. & ERYC65 & $43^{3+}$ & 0 & 0 \\
\hline \multirow[t]{2}{*}{ Dilleniaceae } & Tetracera akara (Burm. f.) Merr. & TETRAK & $19^{1}$ & 0 & 0 \\
\hline & Tetracera korthalsii Miq. & TETRKO & 0 & $93^{3+}$ & $1^{1}$ \\
\hline \multirow[t]{2}{*}{ Euphorbiaceae } & Omphalea bracteata Merr. & OMPHBR & 0 & $32^{2}$ & 0 \\
\hline & Omphalea sargentii Merr. & OMPHSA & $45^{2}$ & 0 & 0 \\
\hline \multirow[t]{8}{*}{ Fabaceae } & Aganope heptaphylla (L.) Polhill. & AGANHE & 0 & $14^{2}$ & 0 \\
\hline & Bauhinia sp. & BAUHM4 & $38^{3+}$ & $4^{2}$ & 0 \\
\hline & Caesalpinia parviflora Prain ex King & CAESPA & $22^{3+}$ & 0 & 0 \\
\hline & Callerya nieuwenhuisii (J.J.Sm.) A.M.Schot & MILLNI & $71^{3+}$ & 0 & 0 \\
\hline & Spatholobus ferrugineus Benth. & SPATFE & 0 & $1^{1}$ & $14^{2}$ \\
\hline & Spatholobus maingayi Prain ex King & SPATMG & 0 & $82^{3+}$ & 0 \\
\hline & Spatholobus oblongifolius Merr. & SPATOB & $104^{3+}$ & 0 & 0 \\
\hline & Spatholobus viridis H.Wiriadinata \& J.W.A.Ridder-Numan & SPATVI & $22^{3}$ & $46^{2}$ & 0 \\
\hline \multirow[t]{2}{*}{ Gnetaceae } & Gnetum gnemonoides Brongn. & GNETGN & 0 & $68^{3}$ & $13^{2}$ \\
\hline & Gnetum neglectum Blume & GNETNE & 0 & 0 & $95^{3+}$ \\
\hline Loganiaceae & Strychnos ignatii P.Bergius & STRYIG & $21^{3+}$ & 0 & 0 \\
\hline Malpighiaceae & Hiptage sp. & HIPTBO & $98^{3+}$ & 0 & 0 \\
\hline \multirow[t]{2}{*}{ Menispermaceae } & Coscinium fenestratum Colebr. & COSCFE & $19^{1}$ & $1^{1}$ & 0 \\
\hline & Hypserpa nitida Miers ex. Benth. & HYPSNI & 0 & $1^{1}$ & $29^{3+}$ \\
\hline Nepenthaceae & Nepenthes sp.1 & NEPEM1 & 0 & 0 & $20^{3+}$ \\
\hline Rhamnaceae & Ventilago dichotoma Merr. & VENTDI & 0 & $36^{3+}$ & $4^{1}$ \\
\hline \multirow[t]{2}{*}{ Rutaceae } & Luvunga sp.1 & LUVUM1 & 0 & $80^{3+}$ & 0 \\
\hline & Luvunga sp.2 & LUVUM2 & $15^{3+}$ & 0 & 0 \\
\hline Santalaceae & Dendrotrophe varians (Blume) Miq. & DENDVA & 0 & 0 & $30^{3+}$ \\
\hline Thymelaeaceae & Linostoma pauciflorum Griffe. & LINOPA & $0^{-}$ & $16^{3}$ & $32^{3+}$ \\
\hline
\end{tabular}

The species codes correspond to those in Figure 4. The number of lianas in 0.75 ha on each soil type is given for each species. The number of plots on which the species was found for each habitat is shown in superscript next to the number of individuals. Significant habitat associations for individual species, whether positive $(+)$ or negative $(-)$, are also shown in superscript.

Within habitats, plots within kerangas forest were most similar to each other (mean $C_{\mathrm{s}}=0.95$ ), whereas sandstone $(0.87)$ and alluvial plots $(0.77)$ had greater variation in the species present in the three plots in each habitat.

The null hypothesis of no difference in species composition among habitats was rejected in the
MRPP analysis, and the effect size was large $(A=0.48, p<0.0001)$. These results confirm the graphical representation of the ordination showing clustering by habitat (Figure 3). All three pair-wise combinations of MRPP analyses among habitats demonstrated clear separation by their liana community: alluvial vs. sandstone hill $A=0.40$, 


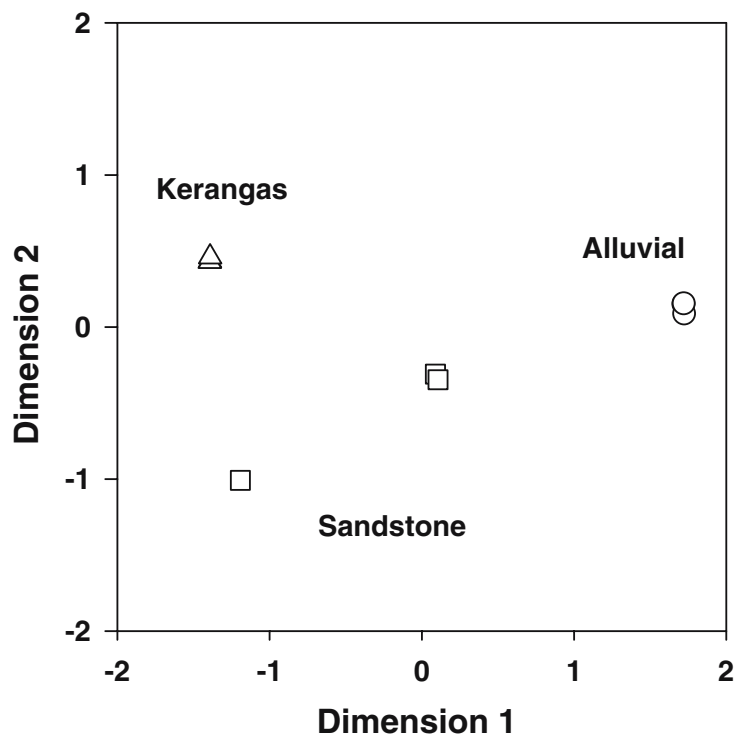

Figure 3. Non-metric multidimensional scaling ordination providing the best fit (least stress) for a two-dimensional solution of liana species presence/absence (stress $=0.2$ ) of 71 liana species that occurred in at least two plots at Sepilok Forest Reserve, Malaysia. Each point represents one of three plots in each of the three habitats. Alluvial plots are represented by circles, sandstone plots with squares, and kerangas with triangles. One point each for alluvial and kerangas plots is obscured by other points for the same habitat.

$p=0.02$; alluvial vs. kerangas $A=0.51, p=0.02$; and sandstone hill vs. kerangas: $A=0.37, p=0.02$.

\section{Species-habitat associations}

Thirty of the 42 species $(71 \%)$ showed at least one significant habitat association: 28 species showed positive associations and three species showed negative associations (Figure 4). One species, $\mathrm{Li}$ nostoma pauciflorum (species code: LINOPA), showed two significant associations in the randomization tests - a positive association with kerangas forest and a negative association with alluvial forest. The remaining 12 species were not significantly associated with any of the habitats and are shown in the intersection of the three circles representing the three habitats in Figure 4. Kerangas and alluvial forests seemed to have greater effects on liana species distributions than sandstone hill forest because 31 and $28 \%$ of species were significantly positively or negatively associated with these habitats, whereas only $12 \%$ were associated with sandstone hill forest.

\section{Discussion}

We found strong evidence of three distinct liana communities at Sepilok in the three habitats. Sandstone hill forests were intermediate between the extremes of alluvial and kerangas forests in almost all aspects of floristics and forest structure, and fewer species showed significant habitat associations with this habitat type. The density of small lianas was similar among forest types, but lianas had larger maximum sizes in alluvial forest than in sandstone hill or kerangas forest, leading to greater liana basal area in alluvial forest. Despite the similar density of small lianas among forest types, greater species diversity was found in alluvial forests than the other forest types. Liana species composition also differed greatly among forest types.

\section{Floristic patterns associated with habitat types}

We found strong patterns of habitat association with liana species associated with only one habitat and seemingly specialized on one of the three soil types. Even using the relatively conservative randomization test, $71 \%$ of liana species were associated either positively or negatively with one soil type. Owing to the spatial clustering of our plots by habitat type, it is possible that the habitat associations we found resulted from dispersal limitation and colonization history. This is unlikely, however, because under a strictly dispersalassembly hypothesis, the alluvial forest should have had the least distinct flora because the alluvial plots were situated geographically between the plots of the other two habitats (Figure 1). Instead, we found that the sandstone hill forest plots, not the alluvial forest, were intermediate in species composition (Figure 3). We therefore suggest that the strong habitat associations found at Sepilok are caused primarily by habitat specialization rather than by limited dispersal. This pattern should be corroborated by sampling the same habitat types at a wider scale. In addition, experimental tests of association (e.g., Fine et al. 2004) could be conducted to corroborate our findings.

The percentage of lianas showing a significant positive or negative habitat association was comparable to that found for trees in a companion study at Sepilok among the three soil types ( $c a$. 


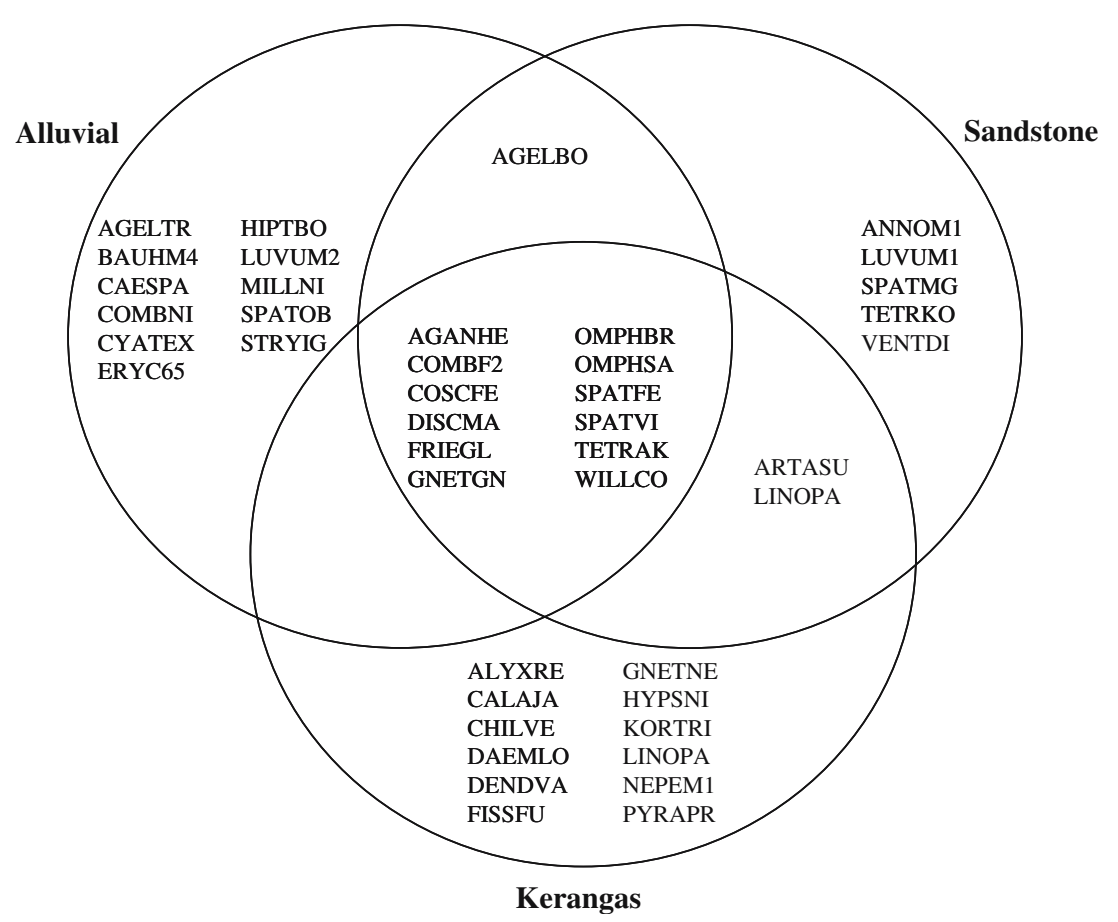

Figure 4. Venn diagrams showing significant habitat associations of abundant liana species with habitats defined by soil types. A positive association with a habitat is indicated by the species code (defined in Table 2) found in the circle of that habitat, whereas a negative association with a habitat is indicated by the species code in the intersection of the other two habitats. For example, AGELBO is negatively associated with kerangas. Note that LINOPA appears twice because it was positively associated with kerangas and negatively associated with alluvial forest.

$67 \%$; D.F.R.P. Burslem et al., unpublished data). However, the patterns of habitat association differed between lianas and trees with a substantially greater percentage of lianas $(29 \%)$ than trees $(12 \%)$ showing positive associations with kerangas, and a lower percentage of lianas than trees showing negative associations with alluvial $(5 \%$ vs. $13 \%)$ and kerangas ( $2 \%$ vs. $13 \%)$ habitats. There seem to be few soil-type generalist tree and liana species at Sepilok. Only the lianas Cyathostemma excelsum and Korthalsia rigida were found on at least two plots on all three soil types, but both were considered habitat specialists because of their greater abundance on alluvial and kerangas soil types, respectively. The majority of lianas considered generalists (i.e., found in the intersection of the circles of the Venn diagram in Figure 4) only occurred on two of the three soil types.

Although it is not possible to make specific comparisons of habitat association with other studies because of differences in sampling designs (number and size of plots) and magnitude of environmental differences (i.e., definition of 'habitat'), general comparisons with other studies can be informative. As with the Sepilok trees and lianas, the most common tree species at Gunung Palung National Park in southwestern Borneo were distributed non-randomly among five habitats defined by elevation, soil parent material, amount of organic material, and drainage $(67 \%$ showed significant habitat associations; Cannon and Leighton 2004). In that study, the majority of the positive and negative associations were with a peat habitat defined by a deep layer of accumulated organic matter overlaid on white sands. Within the Dipterocarpaceae at Gunung Palung, $82 \%$ of species were significantly associated with one of three different parent materials (alluvium, sedimentary, and granite parent materials) and the same percentage were significantly associated with soil nutrients (Paoli et al. 2006). In contrast, Webb and Peart (2000) examined one of the habitats defined by Cannon and Leighton (2004) in more detail (dipterocarp hill forest on granite parent rock) for finer-scale habitat associations among 
ridges, plateaus, and gullies and found that only $35 \%$ of trees $(\geq 10-\mathrm{cm} \mathrm{DBH})$ showed significant habitat associations. Similarly, on Barro Colorado Island (BCI) in Panama, only half of the 171 most common trees and shrubs $(\geq 1-\mathrm{cm} \mathrm{DBH})$ showed significant associations with habitats defined by physiography: high plateau, low plateau, slope, swamp, and streamside (Harms et al. 2001). These latter two studies thus found far fewer significant habitat associations along shallow environmental gradients defined by topography than we found along steep environmental gradients. We propose that marked differences in adjacent soil types as we found in northeastern Borneo lead to high degrees of habitat specialization.

These non-random distributions of woody species according to soil type on Borneo are not particularly surprising given the stark differences in $\mathrm{pH}, \mathrm{N}$ availability, and soil water availability generally found between heath (kerangas) forests and mixed dipterocarp forests (Proctor et al. 1983b; Moran et al. 2000). In addition, calcium, magnesium, and potassium concentrations were found to be greater in alluvial soils (udult) than sandstone hill (humult) soils in northwestern Borneo at Lambir Hills, Sarawak (Palmiotto et al. 2004), and total carbon, nitrogen, and phosphorus were greater on alluvium than sedimentary or granitic soils in Gunung Palung National Park in western Borneo (Paoli et al. 2006). Probably because of edaphic discontinuities over short geographic scales, floristic composition was more strongly associated with soil chemical characteristics in northwestern Borneo than with geographic distance (Potts et al. 2002). Indeed, even when floristic similarity is significantly correlated with geographic distance, this relationship may be explained by changes in environmental conditions between sites (Slik et al. 2003). Growth patterns of tree seedlings also support the hypothesis of soil-related habitat specialization; four of six dipterocarp rain forest tree species showed higher growth on their natural soils than on soils to which they were transplanted at Lambir Hills (Palmiotto et al. 2004).

\section{Hypothesized mechanisms for differences among forest types}

Differences among the three forest habitats in disturbance regime, historical factors, or biotic interactions could lead to the observed differences in liana community structure. In particular, if rates of gap formation or sizes of gaps were higher on alluvial soils, liana abundance could be higher in this habitat because lianas proliferate in gaps (Putz 1984; Schnitzer and Bongers 2002). On the other hand, the disturbance regime might be caused by lianas. Lianas are known to compete with trees for water and nutrients and to add a mechanical burden, all of which could make trees more susceptible to falling (Putz 1984). In addition, lianas connect tree canopies, such that multiple trees often are pulled over as a result of one liana-laden treefall (Appanah and Putz 1984; Putz 1984). Higher numbers of lianas would lead to greater interconnectedness among trees and potentially larger gap sizes as a result of more trees being pulled over. We have no information on gap formation rates or gap sizes in the different habitats, although there is some indication that turnover rates may be highest on alluvial soils (Nilus 2004). Nonetheless, we can not evaluate whether this leads to, or is a function of, the observed greater number of lianas.

Differences in soil water availability, nutrient levels, or an interaction between the two may also cause the variation in liana community composition and structure among the three soil types. The ranking of forest types with respect to liana density, biomass, and diversity corresponds to the ranking in soil fertility and inferred soil water availability. Larger lianas, more biomass, and greater diversity occurred on the more nutrientrich and potentially less drought-prone alluvial soils than on kerangas or sandstone hill forest. Many other studies have also failed to tease apart whether water stress, nutrient deficiency, or both contribute to the floristically distinct vegetation in kerangas forests (Brünig 1971; Richards 1996; Moran et al. 2000). The two variables often covary, and soil water availability may limit soil fertility (Marrs et al. 1991; Burslem et al. 1996).

If there are differences among soil types with regard to soil water availability, then this variation may also help structure the liana community. Soil water availability, but not soil nutrients, was positively related to liana abundance and diversity in a study in the Lacandon tropical rain forest of southeast Mexico, where these two variables do not co-vary (Ibarra-Manríquez and MartínezRamos 2002). The long and wide vessels found in 
the water-conducting system of lianas are sensitive to low water availability, and water stress often causes embolisms (air in the conductive vessels; Sperry and Tyree 1988; Ewers et al. 1990; Gartner et al. 1990). Frequent embolisms may limit the maximum diameter to which lianas grow. Thus, drought-prone kerangas soils could lead to lower abundance of large lianas in the kerangas forest.

If kerangas soils are more prone to water shortage, then we would expect that the dominant lianas in kerangas and sandstone hill forest would have mechanisms to avoid or repair embolisms. Indeed, climbing palms (rattans), which were relatively abundant but not diverse in kerangas forest, are thought to have vessels that resist cavitation or have mechanisms that refill vessels such that vascular bundles in old stems rarely are non-functional (Fisher et al. 2002). Gnetum species, which were most abundant in the sandstone and kerangas plots and were among the largest lianas in any habitat, have longer individual vessel members with similar vessel diameters compared to angiosperms (Fisher and Ewers 1995). It remains to be determined whether or not these physiological attributes affect the ability of Gnetum to avoid or refill after embolism. An interesting future project would be to study whether lianas on the three soil types at Sepilok differ in their water-use efficiency, vulnerability to embolism, or ability to refill after embolism.

This study has shown that the liana communities in the three dominant forest types in northeastern Borneo are distinct in their structure and composition. In addition, the patterns in the liana community are consistent with those in the tree community (Nilus 2004). We still lack a mechanistic understanding of how most habitat specialization of trees or lianas occurs, but it seems likely that edaphic factors such as soil fertility and soil water content exert strong selective pressures on establishment, growth, and survival in the forests of northeastern Borneo.

\section{Acknowledgements}

We appreciate the field help of B. Kurzel and numerous field hands employed by the Forest Research Centre at Sepilok. Sally Brock helped create the map of study sites. Comments by
S. Schnitzer, P. Fine, C. Cannon, and three anonymous reviewers as well as discussions with C. Webb improved this manuscript. This work was supported by a BES grant to D.F.R.P. Burslem and other members of the Biotic Interactions in Tropical Rain Forests project.

\section{References}

Acres B.D. and Folland C.J. 1975. The Soil of Sabah. Volume 2: Sandakan and Kinabatangan Districts. Land Resource Division, Ministry of Overseas Development, Tolworth Tower, Surbiton, Surrey, UK.

Appanah S. and Putz F.E. 1984. Climber abundance in virgin dipterocarp forest and the effect of pre-felling climber cutting on logging damage. Malaysian Forester. 47: 335-342.

Ashton P.S. 1964. Ecological studies in the mixed dipterocarp forests of Brunei State. Oxford Forestry Memoirs 25.

Ashton P.S. and Hall P. 1992. Comparisons of structure among mixed dipterocarp forests of north-western Borneo. J. Ecol. 80: $459-481$.

Baltzer J.L., Thomas S.C., Nilus R. and Burslem D.F.R.P. 2005. Edaphic specialization in tropical rain forest trees: physiological correlates and responses to reciprocal transplantation. Ecology 86: 3063-3077.

Bray J.R. and Curtis J.T. 1957. An ordination of the upland forest communities of southern Wisconsin. Ecol. Monogr. 27: $325-349$.

Brünig E.F. 1971. On the ecological significance of drought in the equatorial wet evergreen rain forest of Sarawak (Borneo). In: Flenley J.R. (ed.), The Water Relations of Malesian Forests, Department of Geography, University of Hull, UK, pp. $65-97$.

Brünig E.F. 1974. Ecological Studies in the Kerangas Forests of Sarawak and Brunei. Borneo Literature Bureau, Kuching, Sarawak, Malaysia.

Burnham R.J. 2002. Dominance, diversity and distribution of lianas in Yasuní, Ecuador: who is on top? J. Trop. Ecol. 18: $845-864$.

Burslem D.F.R.P., Grubb P.J. and Turner I.M. 1996. Responses to simulated drought and elevated nutrient supply among shade-tolerant tree seedlings of lowland tropical forest in Singapore. Biotropica 28: 636-648.

Cannon C.H. and Leighton M. 2004. Tree species distributions across five habitats in a Bornean rain forest. J. Veget. Sci. 15: 257-266.

Clark D.B., Clark D.A. and Read J.M. 1998. Edaphic variation and the mesoscale distribution of tree species in a neotropical rain forest. J. Ecol. 86: 101-112.

Clark D.B., Palmer M.W. and Clark D.A. 1999. Edaphic factors and the landscape-scale distributions of tropical rain forest trees. Ecology 80: 2662-2675.

Dent D. 2004. The Mechanistic Basis of Habitat Specialisation in Dipterocarps. Ph.D. dissertation, Aberdeen University, Aberdeen, UK.

DeWalt S.J., Schnitzer S.A. and Denslow J.S. 2000. Density and diversity of lianas along a chronosequence in a central Panamanian tropical forest. J. Trop. Ecol. 16: 1-19. 
Duivenvoorden J.F. 1995. Tree species composition and rain forest-environment relationships in the Middle Caquetá Area, Colombia, NW Amazonia. Vegetatio 120: 91-113.

Ewers F.W., Fisher J.B. and Chiu S.-T. 1990. A survey of vessel dimensions in stems of tropical lianas and other growth forms. Oecologia 84: 544-552.

Fine P.V.A., Mesones I. and Coley P.D. 2004. Herbivores promote habitat specialization by trees in Amazonian forests. Science 305: 663-665.

Fisher J.B. and Ewers F.W. 1995. Vessel dimensions in liana and tree species of Gnetum (Gnetales). Amer. J. Bot. 82: $1350-1357$.

Fisher J.B., Tan H.T.W. and Toh L.P.L. 2002. Xylem of rattans: Vessel dimensions in climbing palms. Amer. J. Bot. 89: 196-202.

Fox J.E.D. 1973. A handbook to Kabili-Sepilok Forest Reserve, Sabah Forest Record No. 9. Borneo Literature Bureau, Kuching, Sarawak, Malaysia.

Gartner B.L., Bullock S.H., Mooney H.A., Brown V.B. and Whitbeck J.L. 1990. Water transport properties of vine and tree stems in a tropical deciduous forest. Amer. J. Bot. 77: $742-749$.

Gentry A.H. 1991. The distribution and evolution of climbing plants. In: Putz F.E. and Mooney H.A. (eds), The Biology of Vines, Cambridge University Press, Cambridge, UK pp. $3-49$.

Harms K.E., Condit R., Hubbell S.P. and Foster R.B. 2001. Habitat associations of trees and shrubs in a 50-ha Neotropical forest plot. J. Ecol. 89: 947-959.

Hubbell S.P. 2001. The Unified Neutral Theory of Biodiversity and Biogeography. Princeton University Press, Princeton, New Jersey, USA.

Ibarra-Manríquez G. and Martínez-Ramos M. 2002. Landscape variation of liana communities in a Neotropical rain forest. Plant Ecol. 160: 91-112.

Magurran A.E. 2004. Measuring Biological Diversity. Blackwell Publishing, Oxford, UK.

Marrs R.H., Thompson J., Scott D. and Proctor J. 1991. Nitrogen mineralization and nitrification in terra firme forest and savanna soils on Ilha de Maraca, Roraima, Brazil. J. Trop. Ecol. 7: 123-137.

McCune B. and Grace J.B. 2002. Analysis of Ecological Communities. MjM Software, Gleneden Beach, Oregon, USA.

Mielke P.W. Jr. 1984. Meteorological applications of permutation techniques based on distance functions. In: Krishnaiah P.R. and Sen P.K. (eds), Handbook of Statistics, Vol. 4. Elsevier, Amsterdam, pp. 813-830.

Minchin P.R. 1987. An evaluation of relative robustness of techniques for ecological ordination. Vegetatio 69: 89-107.

Moran J.A., Barker M.G., Moran A.J., Becker P. and Ross S. 2000. A comparison of the soil water, nutrient status, and litterfall characteristics of tropical heath and mixed-dipterocarp forest sites in Brunei. Biotropica 32: 2-13.

Newbery D.M. and Proctor J. 1984. Ecological studies in four contrasting lowland rain forests in Gunung Mulu National Park, Sarawak IV. Associations between tree distribution and soil factors. J. Ecol. 70: 475-493.

Nilus R. 2004. Effect of Edaphic Variation on Forest Structure, Dynamics, Diversity and Regeneration in a Lowland Tropical Rain Forest in Borneo. Ph.D. dissertation, Aberdeen University, Aberdeen, UK.
Palmiotto P.A., Davies S.J., Vogt K.A., Ashton M.S., Vogt D.J. and Ashton P.S. 2004. Soil-related habitat specialization in dipterocarp rain forest tree species in Borneo. J. Ecol. 92: 609-623.

Paoli G.D., Curran L.M. and Zak D.R. 2006. Soil nutrients and beta diversity in the Bornean Dipterocarpaceae: evidence for niche partitioning by tropical rain forest trees. J. Ecol. 94: 157-170.

Phillips O.L., Nuñez V.P., Monteagudo A.L., Cruz A.P., Zans M.-E.C., Sanchez W.G., Yli-Halla M. and Rose S. 2003. Habitat association among Amazonian tree species: a landscape-scale approach. J. Ecol. 91: 757-775.

Potts M.D., Ashton M.S., Kaufman L.S. and Plotkin J.B. 2002. Habitat patterns in tropical rain forests: a comparison of 105 plots in northwestern Borneo. Ecology 83: 2782-2797.

Proctor J., Anderson J.M., Chai P. and Vallack H.W. 1983a. Ecological studies in four contrasting lowland rain forests in Gunung Mulu National Park, Sarawak I. Forest environment, structure, and floristics. J. Ecol. 71: 237-260.

Proctor J., Anderson J.M., Chai P. and Vallack H.W. 1983b. Ecological studies in four contrasting lowland rain forests in Gunung Mulu National Park, Sarawak I. Litterfall, litter standing crop and preliminary observations on herbivory. J. Ecol. 71: 261-283.

Putz F.E. 1984. The natural history of lianas on Barro Colorado Island, Panama. Ecology 65: 1713-1724.

Richards P.W. 1996. The Tropical Rain Forest: An Ecological Study 2nd ed. Cambridge University Press, Cambridge.

Ruokolainen K., Linna A. and Tuomisto H. 1997. Use of Melastomataceae and pteridophytes for revealing phytogeographical patterns in Amazonian rain forests. J. Trop. Ecol. 13: $243-256$.

Sabatier D., Grimaldi M., Prevost M.F., Guillaume J., Godron M., Dosso M. and Curmi P. 1997. The influence of soil cover organization on the floristic and structural heterogeneity of a Guianan rain forest. Plant Ecol. 131: 81-108.

SAS Institute 2000. SAS/STAT User's Guide, Version 8, Volumes 1, 2, and 3, Cary, North Carolina, USA.

Schnitzer S.A. 2005. A mechanistic explanation for global patterns of liana abundance and distribution. Amer. Nat. 166: $262-276$.

Schnitzer S.A. and Bongers F. 2002. The ecology of lianas and their role in forests. Trends Ecol. Evol. 17: 223-230.

Schnitzer S.A. and Carson W.P. 2001. Treefall gaps and the maintenance of species diversity in a tropical forest. Ecology 82: 913-919.

Schnitzer S.A., Dalling J.W. and Carson W.P. 2000. The impact of lianas on tree regeneration in tropical forest canopy gaps: evidence for an alternative pathway of gap-phase regeneration. J. Ecol. 88: 655-666.

Schnitzer S.A., DeWalt S.J. and Chave J. In press. Censusing and measuring lianas: a quantitative comparison of the common methods. Biotropica.

Slik J.W.F., Poulsen A.D., Ashton P.S., Cannon C.H., Eichhorn K.A.O., Kartawinata K., Lanniari I., Nagamasu H., Nakagawa M., van Nieuwstadt M.G.L., Payne J., Saridan A., Sidiyasa K., Verburg R.W., Webb C.O. and Wilkie P. 2003. A floristic analysis of the lowland dipterocarp forests of Borneo. J. Biogeogr. 30: 1517-1531.

Sperry J.S. and Tyree M.T. 1988. Mechanism of water stressinduced xylem embolism. Plant Physiol. 88: 581-587. 
Svenning J.-C. 1999. Microhabitat specialization in a species-rich palm community in Amazonian Ecuador. J. Ecol. 87: 55-65.

Tuomisto H. and Poulsen A.D. 1996. Influence of edaphic specialization on pteridophyte distribution in neotropical rain forests. J. Biogeogr. 23: 283-293.

Tuomisto H. and Ruokolainen K. 1994. Distribution of Pteridophyta and Melastomataceae along an edaphic gradient in an Amazonian rain-forest. J. Veget. Sci. 5: 25-34.

Tuomisto H., Ruokolainen K., Poulsen A.D., Moran R.C., Quintana C., Cañas G. and Celi J. 2002. Distribution and diversity of pteridophytes and Melastomataceae along edaphic gradients in Yasuní National Park, Ecuadorian Amazonia. Biotropica 34: 516-533.
Tyree M.T., Patiño S. and Becker P. 1998. Vulnerability to drought-induced embolism of Bornean heath and dipterocarp forest trees. Tree Physiol. 18: 583-588.

Vormisto J., Phillips O.L., Ruokolainen K., Tuomisto H. and Vasquez R. 2000. A comparison of fine-scale distribution patterns of four plant groups in an Amazonian rainforest. Ecography 23: 349-359.

Webb C.O. and Peart D.R. 2000. Habitat associations of trees and seedlings in a Bornean rain forest. J. Ecol. 88: 464-478.

Whitmore T.C. 1984. Tropical Rain Forests of the Far East, 2nd ed. Clarendon Press, Oxford, UK.

Wright S.J. 2002. Plant diversity in tropical forests: A review of mechanisms of species coexistence. Oecologia 130: 1-14. 